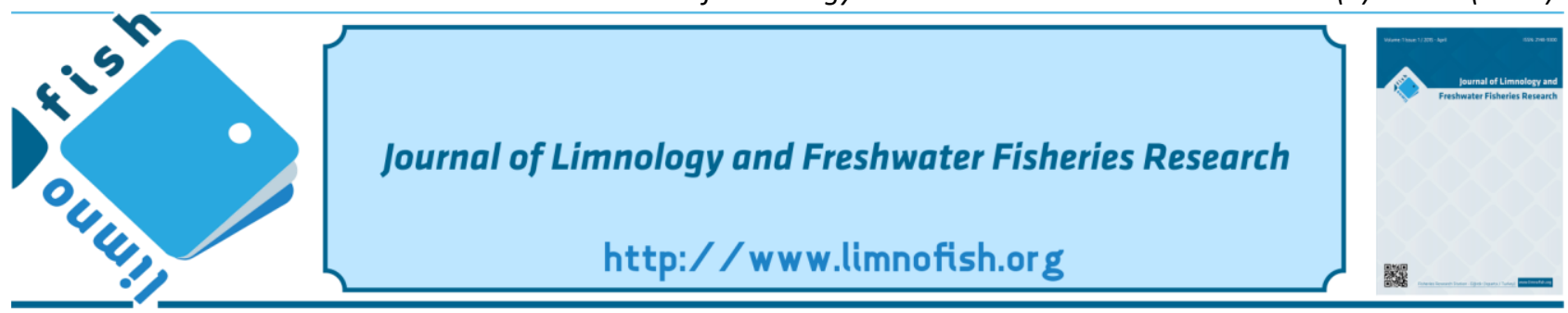

\title{
Phytoplankton Community of a Boron Mine Waste Storage Reservoir
}

\author{
Kemal ÇELIK ${ }^{\text {**iD), Feray ÖZ }}{ }^{1}$ (iD \\ ${ }^{1}$ Balıkesir University, Faculty of Arts and Science, Department of Biology, Çağış Campus, 10145 Balıkesir.
}

\section{A B STRACT}

This study aimed to assess the composition, seasonality, and abundance of the phytoplankton community of a Boron (B) mine effluent storage reservoir, Çamköy Reservoir, Balıkesir, Turkey. For this purpose, phytoplankton and certain physicochemical parameters were sampled seasonally between April 2015 and January 2016. B concentrations ranged from $554 \mathrm{mg} \mathrm{L}^{-1}$ to $689 \mathrm{mg} \mathrm{L}^{-1}$. A total of 39 taxa were identified during the study. The percent composition for each phytoplankton group was as follows: Bacillariophyta $67 \%$, Chlorophyta $10 \%$, Cyanobacteria 8\%, Euglenophyta 8\%, Mioza 5\%, and Charophyta 2\%. In summer 2015 no phytoplankton was detected in the samples and the excessive B concentrations (above $600 \mathrm{mg} \mathrm{L}^{-1}$ ) in the reservoir seem to be the reason for the lack of phytoplankton in the summer samples. The most common taxa were Navicula digitoradiata (Bacillariophyta), Surirella ovata (Bacillariophyta), and Nitzschia amphibia (Bacillariophyta). The reservoir had a low number of phytoplankton taxa and abundance compared with the natural lakes probably due to the excessive B levels. The phytoplankton community of the reservoir was composed of taxa that preferred alkaline waters.

\section{ARTICLE INFO}

\section{RESEARCH ARTICLE}

Received : 16.07 .2020

Revised : :02.10.2020

Accepted :02.10.2020

Published : 29.04.2021

DOI:10.17216/LimnoFish.770638

* CORRESPONDING AUTHOR

kcelik@balikesir.edu.tr

Phone : +902666121000

Keywords: Boron, Çamköy Reservoir, phytoplankton, waste

\section{Bir Bor Madeni Atık Depolama Barajının Fitoplankton Kommunitesi}

Öz: Bu çalışmanın amacı, bir Bor (B) madeni atık toplama barajı, (Çamköy Barajı, Balıkesir) fitoplanktonun kompozisyonu, mevsimselliği ve bolluğunu tespit etmektir. Bu amaçla, Nisan 2015 ile Ocak 2016 tarihleri arasında fitoplankton ve bazı fizikokimyasal parametreler için örnekleme yapılmıştır. B derişimi $554 \mathrm{mg} \mathrm{L}^{-1}$ ile $689 \mathrm{mg} \mathrm{L}^{-1}$ arasında değişmiştir. Çalışma süresince toplamda 39 takson tespit edilmiştir. Fitoplankton kompozisyonu, \%67 Bacillariophyta, \%10 Chlorophyta, \%8 Cyanobacteria, \%8 Euglenophyta , \%5 Mioza ve \%2 Charophyta 'dan oluşmuştur. 2015 yaz döneminde hiç fitoplankton türü tespit edilmemiş olup bunun sebebinin yüksek B seviyelerinin (600 $\mathrm{mg} \mathrm{L}^{-1}$ üzeri) olabileceği tahmin edilmiştir. Tespit edilen en yaygın taksonlar, Navicula digitoradiata (Bacillariophyta), Surirella ovata (Bacillariophyta)_ve Nitzschia amphibia (Bacillariophyta) olmuştur. Yüksek Bor içeriğinden dolayı, doğal göllere nazaran gölette daha düşük fitoplankton takson sayısı ve yoğunluğu tespit edilmiştir. Göletin fitoplankton kommunitesi alkali suları tercih eden taksonlardan oluşmuştur.

Anahtar kelimeler: Bor, Çamköy Barajı, fitoplankton, atık

How to Cite

Çelik K, Öz F. 2021. Phytoplankton Community of a Boron Mine Waste Storage Reservoir LimnoFish. 7(1): 61-68. doi: 10.17216/LimnoFish. 770638

\section{Introduction}

The industrialization has dramatically increased the demand for the mining of minerals worldwide (Stürmer 2013). However, mining has severely affected the sustainability of ecosystems, including surface waters (Lesley et al. 2008). Turkey is one of the leading countries for Boron (B) mining in the world (Türe and Bell 2004). The majority of $\mathrm{B}$ reserves in Turkey are in the western part of the country, including Balıkesir (Türker et al. 2016).
The metalloid $\mathrm{B}$ is naturally present in freshwater bodies at less than $0.1 \mathrm{mg} \mathrm{L}^{-1}$ concentrations, but mining activities have elevated B levels significantly in some water bodies (Nable et al. 1997). The widespread use of B with its high solubility in the water has raised concerns about its excessive levels in some surface waters (Rees et al. 2011).

Although B has been recognized as an essential element for higher plants, studies on B requirements in algae have produced controversial results (Dembitsky et al. 2002; Villavicencio et al. 2007). It 
has been shown that some aquatic plants can accumulate high levels of B (Damiri 2007). Fernandez et al. (1984) found that after seven days of exposure to $\mathrm{B}$, the bioconcentration factor increased significantly in the green alga Chlorella pyrenoidosa H. Chick. Marín and Oron (2007) found that $\mathrm{pH}$ significantly affected the bioaccumulation of $\mathrm{B}$ in the duckweed (Lemna gibba L.).

Phytoplankton populations and their interactions with environmental factors are difficult to generalize. It is more even challenging to examine the interactions between phytoplankton dynamics and water quality parameters in effluent recipient aquatic ecosystems because of their highly dynamic nature (Thomas et al. 2018).

Man-made reservoirs are the main recipients of effluents from mines. Planktonic organisms are directly affected by the effluent inputs. However, our knowledge about phytoplankton in the effluent recipient water bodies is limited. Most of the studies performed so far concentrated on the taxonomy and ecology of phytoplankton in natural waters (Pomati et al. 2017). The resistant phytoplankton species may have adapted to water bodies receiving mine waste.

The link between macronutrient enrichment and increased productivity in lakes is well-established (Schindler 2012). However, the effects of excessive metal concentrations have not been studied comprehensively (Hassler et al. 2012). This study aimed to determine the effects of $\mathrm{B}$ mine effluent on the phytoplankton community composition, seasonality, and abundance in Çamköy Reservoir, Balikesir, Turkey as a B mine effluent storage reservoir.

\section{Materials and Methods \\ Research Area}

Çamköy Reservoir is located at $39^{\circ} 27^{\prime} 43^{\prime \prime} \mathrm{N}$ and $28^{\circ} 10^{\prime} 09^{\prime \prime}$ E, $30 \mathrm{~km}$ southeast of Balıkesir, Turkey (Figure 1). The construction of the reservoir started in 1987 and was completed in 1991 by the State Water Works for effluent deposition from B mine sites. The reservoir has a maximum depth of $33 \mathrm{~m}$ and a surface area of $1 \mathrm{~km}^{2}$. During the mining, a large number of ore is excavated, producing a vast amount of B-rich effluent. The effluent is pumped by pipes from mine sites to the reservoir and it is settled in the bottom (State Water Works 2018).

\section{Field Work and Sampling}

Sampling was carried out seasonally between April 2015 and January 2016. Due to legal restrictions on boat access to the reservoir, samples were taken only at one station. The station was set at the opposite side of the waste entrance point at the edge of the reservoir. Samples were taken below the surface (about $0.5 \mathrm{~m}$ ) using a Kemmerer water sampler. In the field, phytoplankton samples were placed in $250 \mathrm{ml}$ bottles and fixed with Lugol's solution until processed in the laboratory.

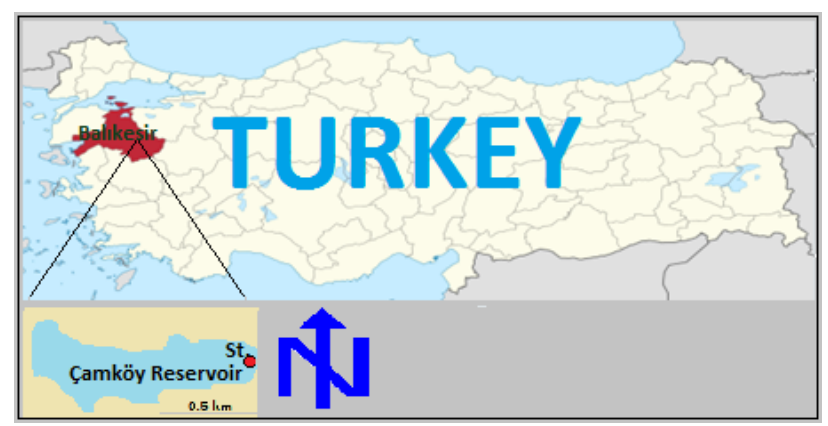

Figure 1. The map showing the location of Çamköy Reservoir and the sampling station in it.

In the laboratory, phytoplankton samples were poured into $50 \mathrm{ml}$ graduated cylinders and were allowed to settle for $24 \mathrm{~h}$. After that, $45 \mathrm{ml}$ of water was aspirated from each graduated cylinder and the remaining $5 \mathrm{ml}$ was poured into a small glass vial for microscopic analysis (APHA 1995). The samples were examined by an Olympus compound microscope. Phytoplankton species were identified according to Bourrelly (1966), Huber-Pestalozzi (1983), Round et al. (1990), Krammer and LangeBertalot (1991), Hartley (1996), John et al. (2002), and Komarek and Anagnostidis (2005). Taxonomic names were updated and based on www.algabase.org (Guiry and Guiry 2020).

In situ parameters including, water temperature, $\mathrm{pH}$, oxidation-reduction potential (ORP), specific conductance (SC), and dissolved oxygen concentration (DO), were measured using a YSI multiprobe. Total suspended solids (TSS) were determined by filtering 1-liter water through Whatman 934-AH filters that were pre-rinsed, dried $\left(105^{\circ} \mathrm{C}\right)$, ashed $\left(550^{\circ} \mathrm{C}\right)$, and tared (APHA 1995). The concentrations of nitrate-nitrogen $\left(\mathrm{NO}_{3}-\mathrm{N}\right)$, soluble reactive, and phosphorus (SRP) were determined spectrophotometrically in the laboratory according to standard methods (APHA 1995).

Water samples for B analysis were placed in 1liter dark plastic bottles and transported to the laboratory in a cooler. Borosilicate glassware was used during the analysis to prevent the contamination of samples. Water samples were adjusted to $\mathrm{pH} 2$ with $\mathrm{HNO}_{3}$ being added to each. B levels were determined by a high-resolution continuum source atomic absorption spectrometer by triplicate measurements in the regional laboratory of the State Water Works in Balıkesir.

The nonparametric Spearman rank correlation test was used to measure the degree of association between physicochemical variables, the total number of phytoplankton taxa, and abundance using SPSS (ver. 11.0) software. 


\section{Results}

Water temperature ranged from $24.8{ }^{\circ} \mathrm{C}$ in August 2015, to $8.7^{\circ} \mathrm{C}$ in January 2016 (Figure 2a). $\mathrm{pH}$ ranged from 9.24 in August 2015, to 8.59 in January 2016 (Figure 2b). SC ranged from $2237 \mu \mathrm{S}$ $\mathrm{cm}^{-1}$ in August 2015, to $736 \mu \mathrm{S} \mathrm{cm}-1$ in January 2016 (Figure 2c).

DO concentrations ranged from $7.4 \mathrm{mg} \mathrm{L}^{-1}$ in August 2015, to $10.84 \mathrm{mg} \mathrm{L}^{-1}$ in January 2016 (Figure 2d). ORP ranged from 21.4 MV in August 2015, to 4.7 MV in January 2016 (Figure 2e). TSS ranged from $2.1 \mathrm{mg} \mathrm{L}^{-1}$ in November 2015 , to $28.9 \mathrm{mg} \mathrm{L}^{-1}$ in August 2015 (Figure 2f).

B concentrations ranged from $554 \mathrm{mg} \mathrm{L}^{-1}$ in April 2015, to $689 \mathrm{mg} \mathrm{L}^{-1}$ in August 2015 (Figure 2g). $\mathrm{NO}_{3}$ $\mathrm{N}$ concentrations ranged from $0.43 \mathrm{mg} \mathrm{L}^{-1}$ in November 2015 , to $0.8 \mathrm{mg} \mathrm{L}^{-1}$ in January 2016 (Figure 2h). SRP concentrations ranged from 0.078 $\mathrm{mg} \mathrm{L}^{-1}$ in November 2015, to $0.09 \mathrm{mg} \mathrm{L}^{-1}$ in August 2015 (Figure 2i).

In Çamköy Reservoir, a total of 39 taxa were identified (Table 1). Bacillariophta made 67\% (26 taxa), Chlorophyta made $10 \%$ (4 taxa), Cyanobacteria made 8\% (3 taxa), Euglenophyta made $8 \%$ (3 taxa), Mioza made 5\% (2 taxa) and Charophyta made $2 \%$ (1 taxon) of the total number of taxa (Figure 3a). The highest number of phytoplankton taxa (23) was obtained in January 2016 and the lowest (0) in August 2015 (Figure 3b). The highest phytoplankton abundance (55531 cell $\mathrm{ML}^{-1}$ ) was obtained in April 2015 and the lowest $\left(0\right.$ cell $\left.\mathrm{ML}^{-1}\right)$ in August 2015 (Figure 3c).

\section{Discussion}

The total number of phytoplankton taxa (39) was lower in Çamköy Reservoir compared with the other reservoirs in the same vicinity. Sevindik et al. (2011) reported 192 phytoplankton taxa from Çaygören Reservoir and 174 taxa from Ikizcetepler Reservoir. The reason for this was probably the excessive B levels in Çamköy Reservoir (Davis et al. 2002; Gunes et al. 2006; Marín and Oron 2007; Saşmaz and Öbek 2009). High levels of B in the reservoir must have prevented the development of sensitive phytoplankton species, resulting in low species numbers due to their low tolerance limits to B toxicity (Reid 2007).

Navicula digitoradiata (avg. 20152 cell $\mathrm{L}^{-1}$ ), Surirella ovata Kützing (avg. 11151 cell L L $^{-1}$ ), and Nitzschia amphibia Kützing (avg. 10151 cell L $^{-1}$ ) were the most abundant diatoms collected during the study. Diatoms of Çamköy Reservoir were stressresistant species. $N$. digitoradiata is one of the rarest diatoms that are found in unique waters with moderate salinity (Zeimann et al. 2001). High ionic content (measured as SC) of this waste storage reservoir may have favored the growth of $N$. digitoradiata.

Fore and Grafe (2002) listed S. ovata as pollution tolerant species in the diatom assemblages of 23 Idaho rivers subjected to human disturbance. They stated that diatoms were robust indicators of metal contamination of natural waters. N. amphibia is commonly collected at sites with heavy metal pollution. Szabo et al. (2005) studied Tisza River in Hungary after the bursting of a mine-storing reservoir to the river and collected high numbers of $N$. amphibia showing that this species is tolerant to metal toxicity.

Chlorophyta was represented by four taxa and they were collected only in spring and fall seasons. Pandorina morum (O.F. Müller) Bory in J.V.Lamouroux, Bory, and Deslongschamps (avg.

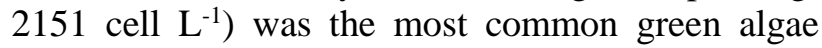
during the study. Anuja and Chandra (2012) conducted a study on a polluted tank and reported that $P$. morum was a pollution indicator species.

The low species number and abundance of green algae could have been due to high levels of B in the reservoir. Garcia-González et al. (1990) provided sound evidence that B was required by marine and freshwater diatoms, whereas green algae did not require it for growth, and they were intolerant to the high B levels.

Cyanobacteria were represented by three taxa (Oscillatoria tenuis C.Agardh ex Gomont (avg. 452 cell $\mathrm{L}^{-1}$ ), Chroococcus minutus (Kützing) Nägeli

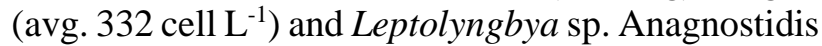
and Komárek (avg. 225 cell L$^{-1}$ ) at low densities. The low species number and abundance of Cyanobacteria in Çamköy Reservoir is probably due to excessive levels of B in the reservoir (Reid 2007). Low levels of $B$ are required for the nitrogen fixation by Cyanobacteria, but excessive levels are toxic for members of this group (Gerloff 1968).

Euglenophyta was represented by three taxa, Trachelomonas granulosa Playfair (avg. 3120 cell $\mathrm{L}^{-1}$ ), Trachelomonas intermedia P.A.Dangeard (avg. 1011 cell $\mathrm{L}^{-1}$ ) and Trachelomonas volvocina (Ehrenberg) Ehrenberg (avg. 853 cell L $^{-1}$ ). Except for summer, euglenoids were present at each sampling period. Euglenoids are abundant in moderately polluted water bodies all over the world ( $\mathrm{Li}$ et al. 2014; Naselli-Flores 2000). Trachelomonas species are known to quickly respond to environmental changes in polluted lakes (Wołowski 2002).

Miozoa was represented by two taxa, Tripos furca (Ehrenberg) F.Gómez (avg. 712 cell L $^{-1}$ ) and Glenodinium sp. Ehrenberg (avg. 312 cell $\mathrm{L}^{-1}$ ). T. furca is a cosmopolitan species mostly collected from salt and brackish waters worldwide (Morton et al. 2011). 

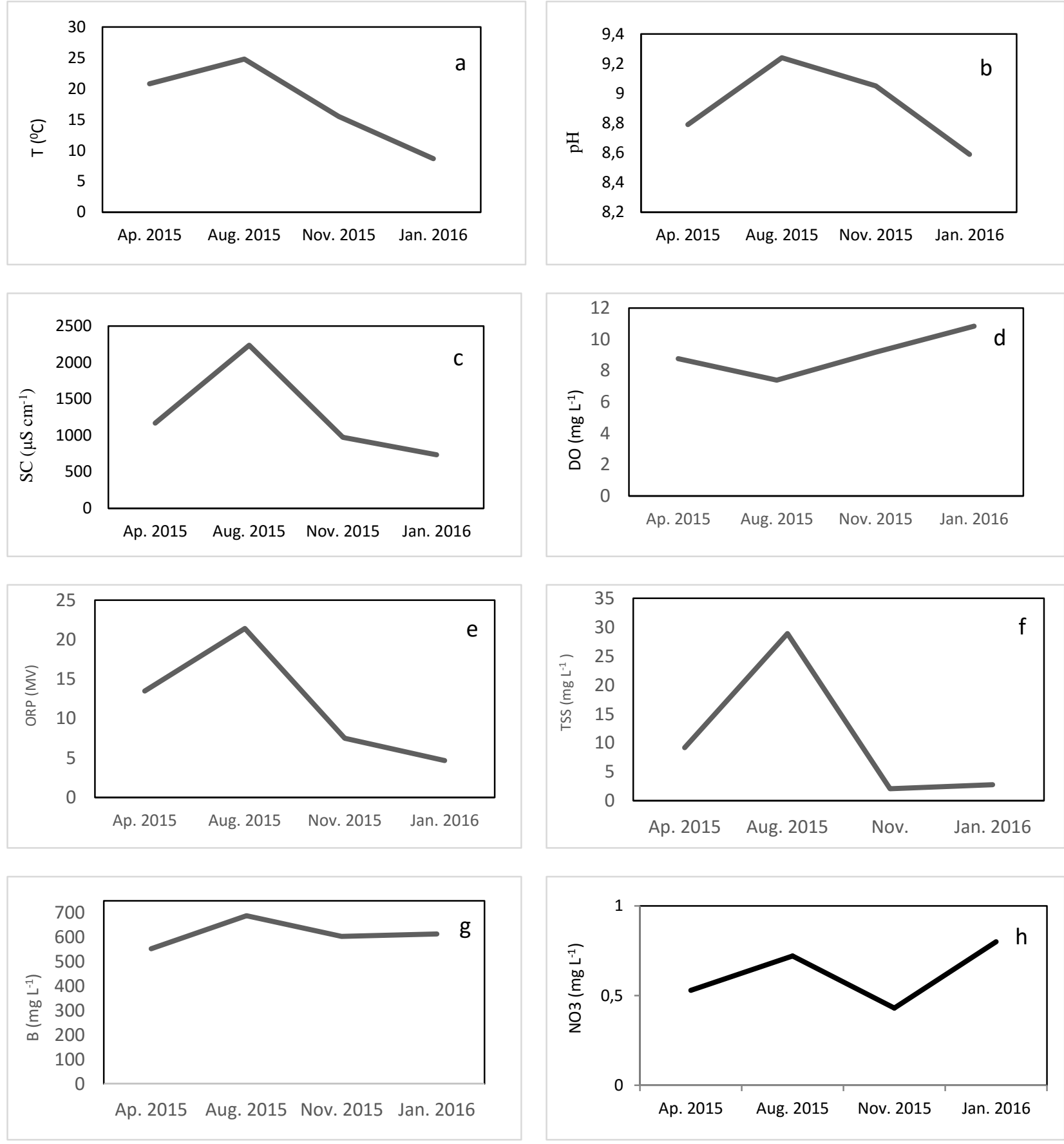

Ap. 2015 Aug. 2015 Nov. 2015 Jan. 2016

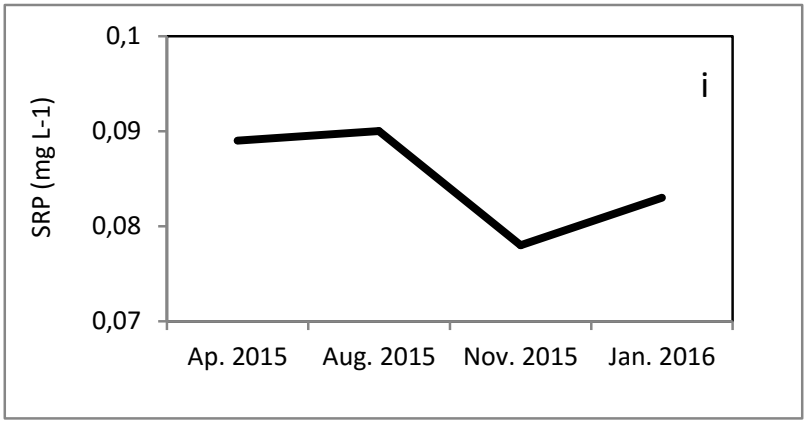

Figure 2. Seasonal variations in a) the water temperature $\left.\left.\left(\mathrm{T} ;{ }^{\circ} \mathrm{C}\right), \mathrm{b}\right) \mathrm{pH}, \mathrm{c}\right)$ specific conductance $\left.\left(\mathrm{SC} ; \mu \mathrm{S} \mathrm{cm}{ }^{-1}\right), \mathrm{d}\right)$ dissolved oxygen (DO; $\mathrm{mg} \mathrm{L}^{-1}$ ), e) oxidation-reduction potential (ORP; MV), f) total suspended solids (TSS; $\mathrm{mg} \mathrm{L}^{-1}$ ), g) Boron $\left.\left(\mathrm{B} ; \mathrm{mg} \mathrm{L}^{-1}\right), \mathrm{h}\right)$ nitrate-nitrogen $\left(\mathrm{NO}_{3}-\mathrm{N} ; \mathrm{mg} \mathrm{L}^{-1}\right)$, i) soluble reactive phosphorus (SRP; $\left.\mathrm{mg} \mathrm{L}^{-1}\right)$ of Çamköy Reservoir 
Table 1. The list of phytoplankton taxa collected from Çamköy Reservoir

\begin{tabular}{|c|c|c|c|c|}
\hline Taxa & Spring & Summer & Fall & Winter \\
\hline \multicolumn{5}{|l|}{ Bacillariophyta } \\
\hline Amphora eximia J.R.Carter 1974 & - & - & - & + \\
\hline Amphora ovalis Kützing 1844 & + & - & - & - \\
\hline Achnanthidium affine (Grunow) Czarnecki 1994 & + & - & - & - \\
\hline Anomoeoneis sphaerophora Pfitzer 1871 & - & - & + & - \\
\hline Aulacoseira italica (Ehrenberg) Simonsen 1979 & - & - & - & + \\
\hline Cymbella caespitosa (Kützing) Brun 1880 & - & - & + & - \\
\hline Fragilaria capucina Desmazières 1830 & + & - & - & - \\
\hline Gomphonema truncatum Ehrenberg 1832 & - & - & - & + \\
\hline Melosira varians C.Agardh 1827 & - & - & - & + \\
\hline Navicula digitoradiata (Gregory) Ralfs 1861 & - & - & + & + \\
\hline Navicula libonensis Schoeman 1970 & + & - & - & - \\
\hline Navicula subtilissima Cleve 1891 & - & - & - & + \\
\hline Nitzschia sp. Hassall 1845 & + & - & - & - \\
\hline Nitzschia pacifica Cupp 1943 & + & - & + & + \\
\hline Nitzschia amphibia Grunow 1862 & - & - & + & - \\
\hline Nitzschia sigmoidea (Nitzsch) W.Smith 1853 & - & - & + & + \\
\hline Pinnularia gibba Ehrenberg 1843 & - & - & + & - \\
\hline Navicula cincta (Ehrenb.) Ralfs 1861 & - & - & + & - \\
\hline Pinnularia hemiptera (Kützing) Rabenhorst 1853 & + & - & - & - \\
\hline Pinnularia microstauron Cleve 1891 & - & - & - & + \\
\hline Pinnularia subrostrata (A.Cleve) Cleve-Euler 1955 & - & - & + & + \\
\hline Stauroneis phoenicenteron (Nitzsch) Ehrenberg 1843 & - & - & - & + \\
\hline Surirella angusta Kützing 1844 & - & - & + & + \\
\hline Surirella minuta Brébisson ex Kützing 1849 & - & - & + & - \\
\hline Surirella ovata Kützing 1844 & + & - & - & - \\
\hline Surirella robusta Ehrenberg 1841 & + & - & - & - \\
\hline \multicolumn{5}{|l|}{ Chlorophyta } \\
\hline Pandorina morum (O.F.Müller) Bory 1824 & + & - & - & - \\
\hline Pediastrum duplex Meyen 1829 & - & - & - & + \\
\hline Pediastrum duplex var. rugulosum Raciborski 1890 & - & - & - & + \\
\hline Pseudopediastrum boryanum (Turpin) E.Hegewald 2005 & - & - & + & - \\
\hline \multicolumn{5}{|l|}{ Euglenophyta } \\
\hline Trachelomonas granulosa Playfair 1915 & + & - & - & - \\
\hline Trachelomonas intermedia P.A.Dangeard 1902 & - & - & + & - \\
\hline Trachelomonas volvocina (Ehrenberg) Ehrenberg 1834 & - & - & - & + \\
\hline Cyanobacteria & & & - & \\
\hline Chroococcus minutus (Kützing) Nägeli 1849 & - & - & - & + \\
\hline Leptolyngbya sp. Anagnostidis \& Komárek 1988 & - & - & + & - \\
\hline Oscillatoria tenuis C.Agardh ex Gomont 1892 & + & - & - & - \\
\hline Charophyta & & & - & \\
\hline Mougeotia C. Agardh 1824 & - & - & - & + \\
\hline \multicolumn{5}{|l|}{ Mioza } \\
\hline Glenodinium sp.Ehrenberg 1836 & - & - & - & + \\
\hline Tripos furca (Ehrenberg) F.Gómez 2013 & - & - & + & + \\
\hline
\end{tabular}



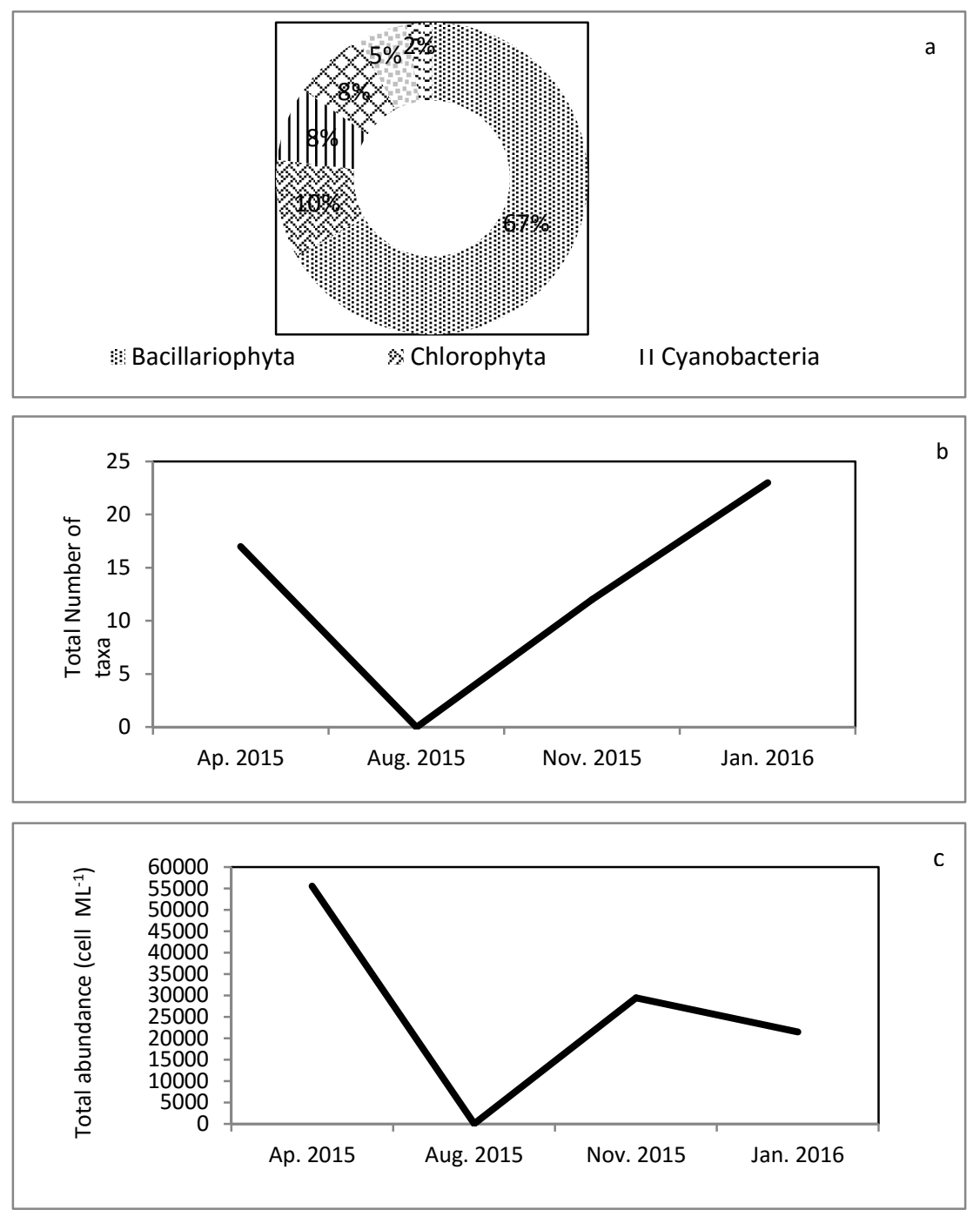

Figure 3. a) The percent composition of the phytoplankton groups, b) the total number of phytoplankton taxa, c) the total abundance of the phytoplankton (cell $\mathrm{ML}^{-1}$ ) of Çamköy Reservoir

Miozoa members, although not absent, are seldom collected in freshwater samples. Glenodinium sp. has been previously reported by Sevindik et al. (2011) in Çaygören Reservoir which is close to Çamköy Reservoir.

In August 2015, no phytoplankters were observed in the samples. The excessive B concentrations (above $600 \mathrm{mg} \mathrm{L}^{-1}$ ) in the reservoir seem to be the reason for the lack of phytoplankton in the summer samples. Reid et al. (2004) found that Chara cells were not affected by the B levels up to $400 \mathrm{mg} \mathrm{L}^{-1}$, but when the concentrations were raised to $600 \mathrm{mg} \mathrm{L}^{-1}$, the cells died in the experimental chamber. It is possible that no phytoplankton species could tolerate B levels greater than $600 \mathrm{mg} \mathrm{L}^{-1}$ in Çamköy Reservoir.

In summary, the nutrient concentrations in Çamköy Reservoir are not at the limiting level for phytoplankton, but the number of taxa and the abundance are low compared with natural lakes. This situation leads to the recognition that the low number of phytoplankton taxa and abundance was a result of the excessive B levels in the reservoir.

\section{References}

Anuja J, Chandra S. 2012. Studies on freshwater algae in relation to chemical constituents of Thiruneermalai temple tank near Chennai, IndiaI. International Journal of Current Science. 4: 21-29.

APHA. 1995. American Public Health Association. Standard methods for the examination of water and wastewater, 19th ed. Washington DC: American Public Health Association. 1100 p.

Bourrelly P. 1966. Les algues d'eau douce - Tome I - les algues vertes. Paris: Nérée Boubée \& Cie $511 \mathrm{p}$.

Damiri B. 2007. Risk Characterization for Boron and Aquatic Plants and Animals [Master's Thesis]. Clemson University. 92 p.

Davis SM, Drake KD, Maier KJ. 2002. Toxicity of boron to the duckweed, Spirodella polyrrhiza. 
Chemosphere $48 \quad$ (6) :615-620. doi: 10.1016/S0045-6535(02)00024-3

Dembitsky VM, Smoum R, Al-Quntar AA, Ali HA, Pergament I, Srebnik M. 2002. Natural occurrence of boron-containing compounds in plants, algae, and microorganisms. Plant Sci. 163(5):931-942. doi: 10.1016/S0168-9452(02)00174-7

Fernandez E, Sanchez E, Bonilla I, Mateo P, Ortega P. 1984. Effect of boron on the growth and cell composition of Chlorella pyrenoidosa. Phyton. 44(2):125-131.

Fore LS, Grafe C. 2002. Using Diatoms to Assess the Biological Condition of Large Rivers in Idaho (USA). Freshwater Biol. 47(10):2015-2037. doi: 10.1046/j.1365-2427.2002.00948.x

Garcia-González M, Mateo P, Bonilla I. 1990. Effect of Boron Deficiency on Photosynthesis and Reductant Sources and Their Relationship with Nitrogenase Activity in Anabaena PCC 7119. Plant Physiol. 93(2) :560-565. doi.org/10.1104/pp.93.2.560

Gerloff GC. 1968. The Comparative Boron Nutrition of Several Green and Blue- Green Algae. Physiol Plant 21: 369-377. doi: 10.1104/pp.93.2.560

Guiry MD, Guiry GM. 2020. Algaebase. [cited 2020 Apr 28]. Available from https://www.algaebase.org/

Gunes A, Soylemezoglu G, Inal A, Bagci EG, Coban S, Sahin O. 2006. Antioxidant and stomatal responses of grapevine (Vitis vinifera L.) to boron toxicity. Sci Hortic-Amsterdam. 110(3):279-284.

doi: 10.1016/j.scienta.2006.07.014

Hartley B. 1996. An Atlas of British Diatoms. Bristol, UK: Biopress Limited 601 p. Hassler CS, Sinoir M, Clementson LA, Butler ECV. 2012. Exploring the Link between

Micronutrients and Phytoplankton in the Southern Ocean during the 2007 Austral Summer. Front Microbiol. 3:1-26. doi: 10.3389/fmicb.2012.00202

Huber-Pestalozzi G. 1983. Das phytoplankton des susswassers - Systematik und biologie, Teil 7, 1. Halfte - Chlorophyceae (Grunalgen) Ordnung: Chlorococcales. Stuttgart. Germany: E.Schweizerbart'sche Verlagsbuchhandlung 1001 p. [in German]

John DM, Whitton BA, Brook AJ. 2002. The Freshwater Algal Flora of the British

Isles: An Identification Guide to Freshwater and Terrestrial Algae. Cambridge, UK: Cambridge University Press 714 p.

Komarek J, Anagnostidis K. 2005. Cyanoprokaryota, Part 2: Oscillatoriales. In: Büdel B, Gärtner G,
Krienitz L, Schagerl M, editors. Süßwasserflora von Mitteleuropa [Freshwater Flora of Central Europe], Bd. 19(2). Germany: Springer Spektrum. p. 1-759.

Krammer K, Lange-Bertalot H. 1991. Bacillariophyceae 4.Teil Achnanthaceae, Kritische Ergänzungen zu Achnanthes s.l., Navicula s. str., Gomphonema. In: Ettl H, Gärtner G, Heynig H, Mollenhauer D, editors. Süßwasserflora von Mitteleuropa [Freshwater Flora of Central Europe], Bd 2/4. Germany: Springer Spektrum . p. 1-468.

Lesley B, Daniel H, Paul Y. 2008. Iron and manganese removal in wetland treatment systems: rates, processes and implications for management. Sci Total Environ. 394(1):1-8. doi: 10.1016/j.scitotenv.2008.01.002

Li M, Gao X, Wu B, Qian X, Giesy JP, Cui Y. 2014. Microalga Euglena as a bioindicator for testing genotoxic potentials of organic pollutants in Taihu Lake, China. Ecotoxicology. 23: 633-640.

doi: 10.1007/s10646-014-1214-x

Marín CMDC, Oron G. 2007. Boron removal by the duckweed Lemna gibba: a potential method for the remediation of boron-polluted waters. Water Res. 41(20):4579-4584. doi: 10.1016/j.watres.2007.06.051

Morton SL, Shuler A, Paternoster J, Fanolua S, Vargo D. 2011. Coastal eutrophication, land use changes and Ceratium furca (Dinophyceae) blooms in Pago Pago Harbor, American Samoa 2007-2009. Chin J Oceanol Limn. 29(4): 790-794.

doi: 10.1007/s00343-011-0507-7

Nable RO, Bañuelos GS, Paull JG. 1997. Boron toxicity. Plant Soil. 193:181-198. doi: 10.1023/A:1004272227886

Naselli-Flores L. 2000. Phytoplankton assemblages in twenty-one Sicilian reservoirs: relationships between species composition and environmental factors. Hydrobiologia 424:1-11. doi: 10.1007/978-94-017-3488-2_1

Pomati F, Matthews B, Seehausen O, Ibelings BW. 2017. Eutrophication and climate warming alter spatial (depth) co-occurrence patterns of lake phytoplankton assemblages. Hydrobiologia 787:375-385.

doi: 10.1007/s10750-016-2981-6

Rees R, Robinson BH, Menon M, Lehmann E, Gunthardt-Goerg MS, Schulin R. 2011. Boron accumulation and toxicity in hybrid poplar (Populus nigra $\mathrm{x}$ euramericana). Environ Sci Technol. 45(24):10538-10543. doi: 10.1021/es201100b 
Reid RJ, Hayes JE, Post A, Stangoulis JCR, Graham RD. 2004. A critical analysis of the causes of boron toxicity in plants. Plant Cell Environ. 25(11): 1405-1414.

doi: 10.1111/j.1365-3040.2004.01243.x

Reid R. 2007. Update on boron toxicity and tolerance in plants. In: Xu F, Goldbach HE, Brown PH, Bell RW, Fujiwara T, Hunt CD, Goldberg S, Shi L, editors. Advances in Plant and Animal Boron Nutrition. Dordrecht, The Netherlands: Springer. p. 83-90.

Round FE, Crawford RM, Mann DG. 1990. Diatoms: Biology and Morphology of the Genera. Cambridge, UK: Cambridge University Press $747 \mathrm{p}$.

Schindler DW. 2012. The dilemma of controlling cultural eutrophication of lakes. P Roy Soc B-Biol Sci. 279(1746): 4322-4333. doi: $10.1098 /$ rspb.2012.1032

Sevindik TO, Çelik K, Gönülol A. 2011. Twenty new records for Turkish freshwater algal flora from Çaygören and Ikizcetepeler Reservoirs (Balikesir, Turkey). Turk J Fish Aquat Sc. 11:399-406. doi: 10.4194/1303-2712-v11_3_09

State Water Works 2018. Baraj ve Göletler; [cited 2018 Jul 15]. Available from http://bolge25.dsi.gov.tr

Stürmer M. 2013. What drives mineral commodity markets in the long run? [PhD Thesis]. Rheinische Friedrich-Wilhelms-Universität Bonn. 241 p.

Szabo K, Kiss KT, Taba G, Acs E. 2005. Epiphytic diatoms of the Tisza River, Kisköre

Reservoir and some oxbows of the Tisza River after the cyanide and heavy metal pollution in 2000 . Acta Bot Croat. 64(1):1-46.

Şaşmaz A, Öbek E. 2009. The accumulation of arsenic, uranium, and boron in Lemna gibba L. exposed to secondary effluents. Ecol Eng. 35(10):1564-1567.

doi: 10.1016/j.ecoleng.2009.06.007

Thomas MK, Fontana S, Reyes M, Kehoe M, Pomati F. 2018. The predictability of a lake phytoplankton community, over timescales of hours to years. Ecol Lett. 21(5): 619-628.

doi: 10.1111/ele.12927

Türe C, Bell RW. 2004. Plant distribution and its relationship to extractable boron in naturally occurring high boron soils in Turkey. Isr J Plant Sci. 52(2):125-132. doi: 10.1560/LDYY-T420-W5LT-JN9Y

Türker OC, Türe C, Böcük H, Yakar A, Chen Y. 2016. Evaluation of an innovative approach based on prototype engineered wetland to control and manage boron (B) mine effluent pollution. Environ Sci Pollut R. 23(19):19302-19316. doi: 10.1007/s11356-016-7122-2

Villavicencio MS, Silva CA, Arce GM. 2007. Boron toxicity in Lemna gibba. Hidrobiologica 17(suppl. 1):1-6.

Wołowski K. 2002. Phylum Euglenophyta. In: John DM, Whitton BA, Brook AJ, editors. The freshwater algal flora of the British Isles: An Identification Guide to Freshwater and Terrestrial Algae. Cambridge, UK: Cambridge University Press. p. 144-179.

Zeimann H, Kies L, Schulz CJ. 2001. Desalinization of Running Waters III. Changes in the Structure of Diatom Assemblages Caused by a Decreasing Salt Load and Changing Ion Spectra in the River Wipper (Thuringia, Germany). Limnologica. 31(4):257-280. doi: 10.1016/S0075-9511(01)80029-3 